\title{
Binding of industrial deposits of heavy metals and arsenic in the soil by 3-Aminopropyltrimethoxysilane
}

\author{
Piotr Grzesiak $^{1 *}$, Joanna Lukaszyk ${ }^{1}$, Grzegorz Schroeder ${ }^{2}$, Joanna Kurczewska² \\ ${ }^{1}$ Institute of Plant Protection - National Research Institute, Department of Ecology and Environmental Protection, \\ ul. W. Węgorka 20, 60-318 Poznań, Poland \\ ${ }_{2}^{2}$ Adam Mickiewicz University in Poznań, Faculty of Chemistry, ul. Umultowska 89 B, 61-614 Poznań, Poland \\ "Corresponding authors: e-mail: p.grzesiak@iorpib.poznan.pl
}

\begin{abstract}
The results of the research studies concerning binding of heavy metals and arsenic (HM+As), occurring in soils affected by emissions from Głogów Copper Smelter and Refinery, by silane nanomaterial have been described. The content of heavy metals and arsenic was determined by AAS and the effectiveness of heavy metals and arsenic binding by 3-Aminopropyltrimethoxysilane was examined. The total leaching level of impurities in those fractions was $73.26 \% \mathrm{Cu}, 74.7 \%-\mathrm{Pb}, 79.5 \% \mathrm{Zn}, 65.81 \%-\mathrm{Cd}$ and $55.55 \%$ As. The studies demonstrated that the total binding of heavy metals and arsenic with nanomaterial in all fractions was about as follows: $20.5 \% \mathrm{Cu}, 9.5 \% \mathrm{~Pb}$, $7.1 \% \mathrm{Zn}, 25.3 \% \mathrm{Cd}$ and $10.89 \%$ As. The results presented how the safety of food can be cultivated around industrial area, as the currently used soil stabilization technique of $\mathrm{HM}$ by soil $\mathrm{pH}$ does not guarantee their stable blocking in a sorptive complex.
\end{abstract}

Keywords: nanotechnology, heavy metals, soil stabilization.

\section{INTRODUCTION}

Soil is a very important part of the natural environment. It is composed of the mineral part, organic matter, water, air and living organisms, and it provides essential nutrients for plants as well as it is a main link in the trophic chain.

Soil is also a place of industrial waste deposit generated during technological human activity. One of anthropogenic factors being responsible for heavy metals and arsenic $(\mathrm{HM}+\mathrm{As})$ depositing in the soil environment are industrial emissions, including emissions from non-ferrous metal smelters ${ }^{1}$. The presence of harmful impurities in the surface-humus soil is potentially dangerous, as these chemicals can persist for a long time in environment. An increased content of these contaminations in the soil influences plant communities and other mechanisms of the food chain. They can induce numerous disturbances in human and animal metabolism ${ }^{2}$ while adversely affecting soil microorganisms and soil properties. Their potential harmfulness is caused by a sorption of trace elements by the soil complex, which in turn changes the chemistry of soil processes and influences negatively the value as well as the agricultural usefulness of soils. As a result of the soil contamination with heavy metals, the reduced species diversity of soil microorganisms as well as the decreased amount of enzymes produced by them are observed ${ }^{3}$. Furthermore, owing to a lower density of soil fauna, the fertility of the soil deteriorates, which is the disturbance consequence of the mineralization process of organic manner, as well as the soil structure and its permeability get worsen ${ }^{4}$.

Mobility of heavy metals in soil depends on soil solution $\mathrm{pH}$. The areas affected by the industrial impact, are characterized by both dust emission and gas emission which are strongly acid-forming. This type of emission is responsible for the dynamics of heavy metal stabilization processes taking place in soil environment. The most common method, applied in the areas being under the industrial influence (large areas), is the chemical reduction of these contaminants, mobility through a stabilization of soil acidity. In such conditions, heavy metals occur as soluble hydroxides ${ }^{3,5}$. Despite the effectiveness of this technique, it does not guarantee totally the safety of food, due to fluctuations of gas emissions and progressive increase of soil acidity. The presence of such mechanism indicates the necessity of continuous monitoring of those areas and taking of appropriate agronomic treatments leading to the stabilization of pollutants in forms unavailable for plants. The disadvantage of this technique is the limited number of cultivations.

The topic concerning industrial deposits is of particular importance due to the changes in legislation caused by the new EU directive on industrial emissions (IED). This directive describes the conditions necessary to obtain an integrated permit - a permit for business management, but also defines soil as an arable layer ${ }^{6}$.

\section{THE APPLICATION OF NANOTECHNOLOGY IN ENVIRONMENTAL PROTECTION AND AGRICULTURE}

The application of nanotechnology in environmental protection, agriculture and plant protection has just begun $^{4,7}$ and can quickly improve the quality and quantity of crops, while reducing the quantity of plant protection products ${ }^{5,8}$. Changes in agricultural technology are a major factor in the shaping of modern agriculture. In recent years, nanotechnology has occupied a significant position (in the area of technological developments in innovation) in the transformation of agriculture and food production ${ }^{6-10}$. These innovative actions include soil, more effective and more targeted utilization of the means of production, new formulations containing toxins for pest control, new crops as well as diversification of agricultural practices and products in large and homogenous production systems.

\section{EXPERIMENTAL}

The research studies were carried out on the soil taken from the area of Głogów Copper Smelter and Refinery 
impact zone $\mathrm{e}^{\mathbf{8}, \mathbf{1 1}}$. The soil was sieved in order to separate solid impurities and dried in $105^{\circ} \mathrm{C}$ to constant weight (soil moisture below $0.5 \%$ ). Then the grain size was determined by laser meter of particle size MicroTec 22, while the porosity - by mercury porosimetry using Pascal 240 porosimeter, ${ }^{\mathbf{9}}$ - Table 1 . The dry soil was sampled, milled for two minutes in a planetary mill Pulverisette 7 in order to homogenize the sample. Furthermore, the total content of heavy metals and arsenic was determined by AAS - Atomic Absorption Spectrometry as shown in - Table 1. The effectiveness of heavy metals and arsenic binding by 3-Aminopropyltrimethoxysilane (Scheme 1) was examined.

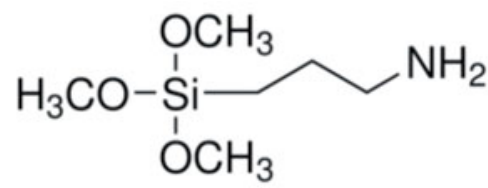

Scheme 1. Structural formula of 3-Aminopropyltrimethoxysilane - CAS number 919-30-2, production Innosil Sp. z o.o

The research studies were carried out in the following conditions: the sample weight of about $25.9 \pm 0.1 \mathrm{~g}$, the concentration of the nano-agent in a solution $-0.1 \%$ and $0.5 \%$, the volume of the dosing the nano-agent solution $-2.5 \mathrm{~cm}^{3}$, the soil moisture after the nano-agent introduction $-16 \%$. The measured volume of the nano-agent solution was mixed precisely with soil and left for 4 days. Every day the sample was thoroughly mixed and a constant soil moisture was kept. The reference sample, without nano-agent addition, was also prepared (sample "0").

The soil samples were exposed to a five-step Tessier sequential extraction, using the same soil sample with stronger and stronger extractants ${ }^{\mathbf{1 3}}$. The sequential extraction is a very important source of the information about the speciation of metals in the soil and their availability for plants. The speciation studies included the differentiation and identification four defined fractions (occurring form) of impurities (Table 2) according to the following scheme. The last fraction for this method consists of metals bound with aluminosilicates. The release of those metals requires strong agents $\left(10 \mathrm{M} \mathrm{HNO}_{3}\right.$ at boiling point). This fraction is no longer available for plants.

For the sequential analysis, $1.0000 \pm 0.0005 \mathrm{~g}$ of the soil sample was weighted. The individual steps of the extraction were carried out in glass centrifuge tubes of 50 $\mathrm{ml}$. The solution acidity was stabilized at each stages of the extraction process according to the methodology. The samples were shaken in a horizontal shaker with a thermostatic water bath having a programmable temperature range from $20^{\circ} \mathrm{C}$ to $100^{\circ} \mathrm{C}$ (an accuracy of $\pm 2^{\circ} \mathrm{C}$ ). After each extraction step, the samples were centrifuged for 30 minutes. The supernatant was transferred to a calibrated polypropylene tube with a hermetic seal. The residual precipitate in the centrifuge tube was washed with demineralized water $(5 \mathrm{ml})$, centrifuged again for 30 minutes. The washings were pipette and combined with the first portion of the extract. The content of heavy metals and arsenic was determined in the solutions. The solutions derived from the first three stages of the extraction were acidified with four drops of concentrated nitric acid(V). Heavy metals in the extracts were determined by AAS method, while arsenic by a hydride generation technique using sodium bromide and hydrochloric acid - Table 3.

On the basis of $(\mathrm{HM}+\mathrm{As})$ content in different fractions, the binding coefficients were calculated using equation (1) - Table 4:

$\eta=\frac{c_{o}-c_{i}}{c_{o}} \cdot 100$

where:

$\eta$ - binding coefficient of HM and As in a fraction,

$\mathrm{c}_{\mathrm{o}}-\mathrm{HM}$ content in a fraction in sample $(0)$ without the nano-agent,

$c_{i}-H M$ content in a fraction in sample (i) with the nano-agent.

\section{RESULTS AND DISCUSSION}

The effectiveness studies of heavy metals and arsenic binding in the soil by 3-Aminopropyltrimethoxysilane

Table 1. The metal content, grain size and porous properties of the soil

\begin{tabular}{|l|c|c|}
\hline $\mathrm{HM}+$ As, $\mathrm{mg} / \mathrm{kg}$ & Grain size & Porous properties \\
\hline $\mathrm{Cu}-242.1 \pm 27.2$ & $3.84 \mu \mathrm{m}-$ up to $10 \%$ & Total pore volume $-382.31 \mathrm{~mm}^{3} / \mathrm{g}$ \\
$\mathrm{Pb}-95.9 \pm 21.5$ & $41.25 \mu \mathrm{m}-$ up to $50 \%$ & Average pore radius $-14.15 \mathrm{~nm}$ \\
$\mathrm{Zn}-34.3 \pm 5.5$ & $193.55 \mu \mathrm{m}-$ up to $90 \%$ & Total porosity $-12.47 \%$ \\
$\mathrm{Cd}-1.81 \pm 0.06$ & $193.55-502.51-$ up to $100 \%$ & Bulk density $-0.326 \mathrm{~g} / \mathrm{cm}^{3}$ \\
$\mathrm{As}-7.9 \pm 2.1$ & & Apparent density $-0.373 \mathrm{~g} / \mathrm{cm}^{3}$ \\
\hline
\end{tabular}

Table 2. The methods of extraction and forms of occurrence of heavy metals in soils

\begin{tabular}{|c|c|c|}
\hline Fraction & Form of $\mathrm{HM}$ occurrence & Extraction method \\
\hline $\mathrm{F}_{1}$ & $\begin{array}{l}\text { Exchangeable metals, present in the soil solution in the form of ions } \\
\text { or soluble complex connections with mineral or organic ligands }\end{array}$ & $\begin{array}{l}10 \mathrm{~cm}^{3} 1 \mathrm{M} \mathrm{CH}_{3} \mathrm{COONH}_{4}(\mathrm{pH}=7) \text {, shaking time } 1 \mathrm{~h} \text {, room } \\
\text { temp. }\end{array}$ \\
\hline$F_{2}$ & $\begin{array}{l}\text { Metals associated with carbonates, adsorbed on ion-exchange } \\
\text { positions associated with stable and vari able mineral charges and } \\
\text { organic components of sorption soil complex }\end{array}$ & $\begin{array}{l}20 \mathrm{~cm}^{3} 1 \mathrm{M} \mathrm{CH}{ }_{3} \mathrm{COONa} \text { acidified by } \mathrm{CH}_{3} \mathrm{COOH} \text { to } \mathrm{pH}=5 \text {, } \\
\text { shaking time } 5 \mathrm{~h} \text {, room temp. }\end{array}$ \\
\hline $\mathrm{F}_{3}$ & $\begin{array}{l}\text { Occluded metals with hydrous oxides of iron and manganese or } \\
\text { present therein as a result of intracrystalline diffusion }\end{array}$ & $\begin{array}{l}20 \mathrm{~cm}^{3} 0.04 \mathrm{M} \mathrm{NH}_{2} \mathrm{OH}^{*} \mathrm{HCl} \text { dissolved in } 25 \% \mathrm{CH}_{3} \mathrm{COOH} \text {, } \\
\text { shaking time } 5 \mathrm{~h} \text {, at } 95^{\circ} \mathrm{C} \text { temp. }\end{array}$ \\
\hline $\mathrm{F}_{4}$ & $\begin{array}{l}\text { Metals associated with organic matter, mostly in a form of organo- } \\
\text { metallic complexes formed with the participation of carboxyl } \\
\text { groups; low-molecular weight complexes are characterized by } \\
\text { significant solubility, while high-molecular weight ones are insoluble } \\
\text { in water }\end{array}$ & $\begin{array}{l}5 \mathrm{~cm}^{3} 0.02 \mathrm{M} \mathrm{HNO}_{3}+5 \mathrm{~cm}^{3} 30 \% \mathrm{H}_{2} \mathrm{O}_{2}(\mathrm{pH}=2) \text {, shaking } \\
\text { time } 2 \mathrm{~h} \text {, temp. } 85^{\circ} \mathrm{C} \text {, then } 5 \mathrm{~cm}^{3} 30 \% \mathrm{H}_{2} \mathrm{O}_{2}(\mathrm{pH}=2) \text {, } \\
\text { shaking time } 3 \mathrm{~h} \text {, temp. } 85^{\circ} \mathrm{C} \text { and then } 10 \mathrm{~cm}^{3} 3.2 \mathrm{M} \\
\mathrm{CH}_{3} \mathrm{COONH} \mathrm{H}_{4} \text { in } 20 \% \mathrm{HNO}_{3} \text {, shaking time } 0.5 \mathrm{~h} \text {, room } \\
\text { temp. }\end{array}$ \\
\hline
\end{tabular}


Table 3. Heavy metals and arsenic content in different fractions of soil extracts

\begin{tabular}{|c|c|c|c|c|c|}
\hline \multirow{3}{*}{$\begin{array}{l}\text { Concentration of } \\
\text { agent, } \%\end{array}$} & \multicolumn{5}{|c|}{$F_{1}$} \\
\hline & $\mathrm{Cu}$ & $\mathrm{Pb}$ & $\mathrm{Zn}$ & $\mathrm{Cd}$ & As \\
\hline & \multicolumn{5}{|c|}{$\mathrm{mg} / \mathrm{kg}$} \\
\hline 0 & 19.54 & 0.81 & 3.37 & 0.14 & 0.57 \\
\hline 0.1 & 10.16 & 0.42 & 3.05 & 0.12 & 0.46 \\
\hline \multirow[t]{2}{*}{0.5} & 10.46 & 0.40 & 3.23 & 0.13 & 0.47 \\
\hline & \multicolumn{5}{|c|}{$F_{2}$} \\
\hline 0 & 7.54 & 4.18 & 3.52 & 0.049 & 0.32 \\
\hline 0.1 & 5.37 & 3.35 & 3.06 & 0.036 & 0.28 \\
\hline \multirow[t]{2}{*}{0.5} & 5.37 & 3.34 & 3.12 & 0.036 & 0.29 \\
\hline & \multicolumn{5}{|c|}{$F_{3}$} \\
\hline 0 & 99.37 & 45.51 & 17.39 & 0.68 & 2.14 \\
\hline 0.1 & 80.41 & 40.30 & 17.15 & 0.49 & 1.86 \\
\hline \multirow[t]{2}{*}{0.5} & 81.00 & 41.01 & 17.09 & 0.49 & 1.86 \\
\hline & \multicolumn{5}{|c|}{$\mathrm{F}_{4}$} \\
\hline 0 & 50.85 & 21.14 & 2.99 & 0.31 & 1.37 \\
\hline 0.1 & 45.09 & 20.76 & 2.09 & 0.24 & 1.31 \\
\hline 0.5 & 45.13 & 20.74 & 2.13 & 0.24 & 1.31 \\
\hline
\end{tabular}

Table 4. The binding coefficients $(\mathrm{HM}+\mathrm{As})$ in different fractions of soil extracts

\begin{tabular}{|c|c|c|c|c|c|c|c|c|}
\hline \multirow{3}{*}{$\begin{array}{l}\text { Binding } \\
\text { Fraction } \\
\text { Conc. of agent }\end{array}$} & \multicolumn{8}{|c|}{$\eta, \%$} \\
\hline & \multicolumn{2}{|c|}{$F_{1}$} & \multicolumn{2}{|c|}{$F_{2}$} & \multicolumn{2}{|c|}{$F_{3}$} & \multicolumn{2}{|c|}{$F_{4}$} \\
\hline & 0.1 & 0.5 & 0.1 & 0.5 & 0.1 & 0.5 & 0.1 & 0.5 \\
\hline $\mathrm{Cu}$ & 48.00 & 46.49 & 28.69 & 28.79 & 19.08 & 18.48 & 11.33 & 11.26 \\
\hline $\mathrm{Pb}$ & 48.55 & 50.92 & 19.88 & 20.07 & 11.43 & 9.89 & 1.81 & 1.87 \\
\hline $\mathrm{Zn}$ & 9.41 & 4.23 & 13.18 & 11.24 & 1.36 & 1.72 & 29.89 & 28.57 \\
\hline $\mathrm{Cd}$ & 12.48 & 9.39 & 25.97 & 26.58 & 28.28 & 28.26 & 24.44 & 23.45 \\
\hline As & 18.47 & 16.64 & 11.47 & 9.47 & 12.89 & 12.82 & 4.48 & 4.40 \\
\hline
\end{tabular}

nano-agent have been carried out. The total content of the heavy metals in the soil was as follows: $242.1 \mathrm{mg} \mathrm{Cu} /$ $\mathrm{kg}, 95.9 \mathrm{mg} \mathrm{Pb} / \mathrm{kg}, 34.3 \mathrm{mg} \mathrm{Zn} / \mathrm{kg} 1.81 \mathrm{mg} \mathrm{Cd} / \mathrm{kg}$, and 7.9 $\mathrm{mg} / \mathrm{kg}$ As - Table 1. Most of grains in the examined soil were characterized by the size of $193.55 \mu \mathrm{m}$. The total pore volume was $382.31 \mathrm{~mm}^{3} / \mathrm{g}$ and the average pore radius $-14.15 \mathrm{~nm}$, while the total porosity was $12.47 \%$.

The studies have shown no effect of the nano-agent concentration in the range 0.1 and $0.5 \%$ for the effectiveness of heavy metals and arsenic binding. The differences in the contents of individual impurities were insignificant and in the range of the measurement error.

The total copper content in extracts from four soil fractions was $177.29 \mathrm{mg} / \mathrm{kg}$, lead - $71.63 \mathrm{mg} / \mathrm{kg}$, zinc $27.27 \mathrm{mg} / \mathrm{kg}$, cadmium $1.19 \mathrm{mg} / \mathrm{kg}$ and $4.39 \mathrm{mg} \mathrm{As} /$ $\mathrm{kg}$ - Figure 1. The total leaching level of impurities in those fractions was $73.26 \%$ for copper, lead $-74.7 \%$, zinc $-79.5 \%$, cadmium $-65.81 \%$ and $55.55 \%$ for arsenic. Zinc was extracted strongly, arsenic-poorly. The studies of heavy metals and arsenic content in the soil extracts after binding with the nano-agent, have shown different degrees of the impurity leaching in different fractions of the sequential analysis - Figure 2. The highest leaching of heavy metals and arsenic is observed for the fraction $\mathrm{F}_{3}$ - the occluded metals with hydrous oxides of iron and manganese. Smaller leaching of copper and lead occurs in the fraction $\mathrm{F}_{4}$ - the metals associated with organic matter, and the least one in the fraction $\mathrm{F}_{2}-$ the metals associated with carbonates and organic components of the sorption complex. Zinc demonstrates the highest ability for leaching in the fraction $\mathrm{F}_{3}$, while the lowest in $\mathrm{F}_{4}$. Cadmium and arsenic are preferably eluted in the fraction $\mathrm{F}_{3}$ and the least in the fraction $\mathrm{F}_{2}$. The determination of leaching is important for determining the availability and assimilation of these impurities by plants.
The difference in binding of individual elements by 3-Aminopropyltrimethoxysilane has been found and it depends on the element form in the soil (fraction) - Figure 3. Copper and lead have been bound most strongly in the fraction $\mathrm{F}_{1}$ in approximately $48 \%$, and the percentage decreased for other fractions. The lowest values were observed for the fraction $\mathrm{F}_{4}-11.33 \%$ for copper and $1.81 \%$ for lead. Zinc was bounded differently in the individual fractions. The binding coefficient was about $9.41 \%$ in the fraction $\mathrm{F}_{1}, 13.81 \%$ in the fraction $\mathrm{F}_{2}, 1.36 \%$ in $\mathrm{F}_{3}$ (the lowest) and $29.89 \%$ in $\mathrm{F}_{4}$ (the highest). In case of cadmium the binding coefficient increased from $12.48 \%$ in the fraction $F_{1}$ to $28.28 \%$ in $\mathrm{F}_{3}$, then slightly decreased to $24.44 \%$ in the fraction $\mathrm{F}_{4}$. Arsenic was the best bound in the fraction $\mathrm{F}_{1}(18.47 \%)$, slightly less in $\mathrm{F}_{2}$ and $\mathrm{F}_{3}(11.47$ and $12.89 \%)$, the least in the fraction $\mathrm{F}_{4}$ - only about $4.48 \%$.

The studies demonstrated that the total binding of heavy metals and arsenic with 3-Aminopropyltrimetho-

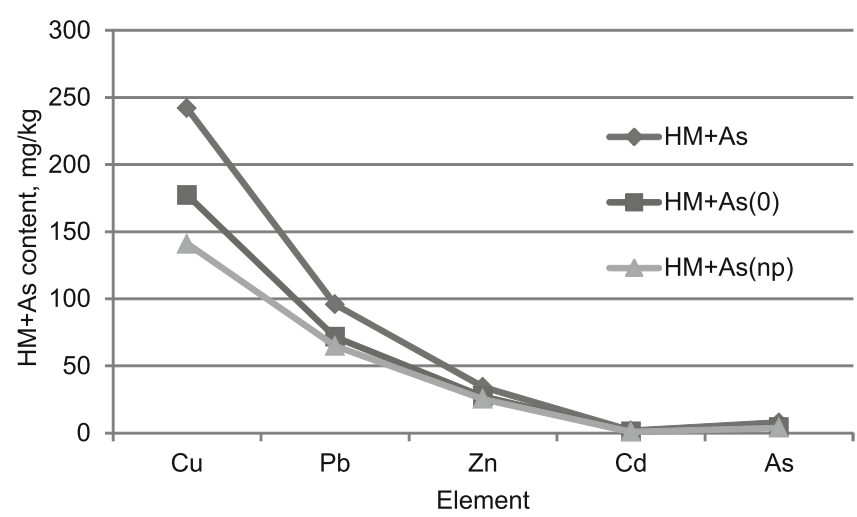

Figure 1. The total extraction of $\mathrm{HM}$ and As from the soil. $\mathrm{HM}+\mathrm{As}-$ the total content in the soil, $\mathrm{HM}+\mathrm{As}(0)$ - the total content in extracts from the soil without the nano-agent, $\mathrm{HM}+\mathrm{As}(\mathrm{np})$ - the total content in extracts from the soil with the nano-agent 


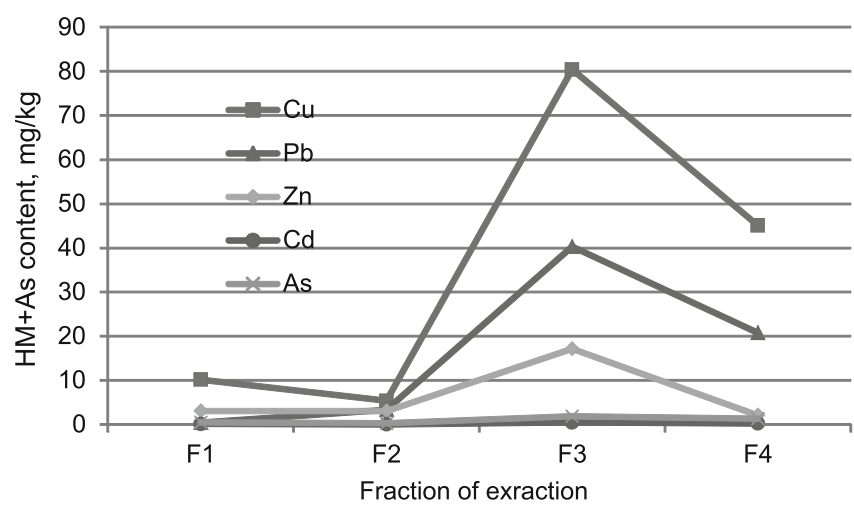

Figure 2. The quantity of $\mathrm{HM}$ and As leaching in the individual fractions of the soil

xysilane in all fractions was about as follows: $20.5 \% \mathrm{Cu}$, $9.5 \% \mathrm{~Pb}, 7.1 \% \mathrm{Zn}, 25.3 \% \mathrm{Cd}$ and $10.89 \%$ of arsenic Figure 4 . The nano-agent has an ability of the strongest binding in the soil of cadmium and copper, weaker - lead and arsenic, and the weakest - zinc.

In some areas affected by the influence of Głogów Copper Smelter and Refinery can be deposited about $382 \mathrm{mg} \mathrm{HM}+\mathrm{As} / \mathrm{kg}$ (about $242.1 \mathrm{mg} \mathrm{Cu} / \mathrm{kg}, 95.9 \mathrm{mg} \mathrm{Pb} /$ $\mathrm{kg}, 34.3 \mathrm{mg} \mathrm{Zn} / \mathrm{kg}, 1.8 \mathrm{mg} \mathrm{Cd} / \mathrm{kg}$ and $7.9 \mathrm{mg} \mathrm{As} / \mathrm{kg}$ ) in the soil. The fractions available for plants contain about $281.8 \mathrm{mg} \mathrm{HM} / \mathrm{kg}$ (about $177.3 \mathrm{mg} \mathrm{Cu} / \mathrm{kg}, 71.6 \mathrm{mg} \mathrm{Pb} / \mathrm{kg}$, $27.3 \mathrm{mg} \mathrm{Zn} / \mathrm{kg}, 1.19 \mathrm{mg} \mathrm{Cd} / \mathrm{kg}$ and $4.4 \mathrm{mg} \mathrm{As} / \mathrm{kg}$ ). The rest of harmful deposit in unavailable for plants. Their availability requires very radical chemical activity, which does not take place in the soil conditions.

The use of 3-Aminopropyltrimethoxysilane nano-agent allows to permanent limit the availability of all discussed impurities for plants by about $16 \%$, ie. to about $236 \mathrm{mg}$

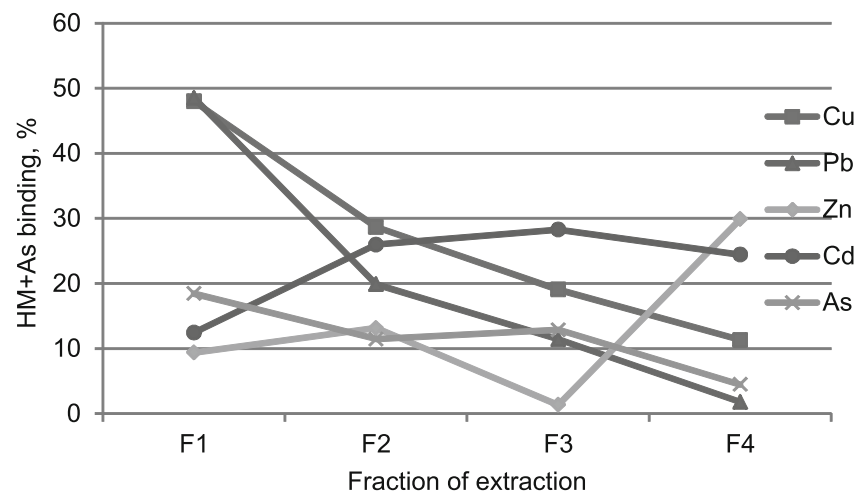

Figure 3. The binding coefficients of HM and As by the nano-agent in separate soil fractions

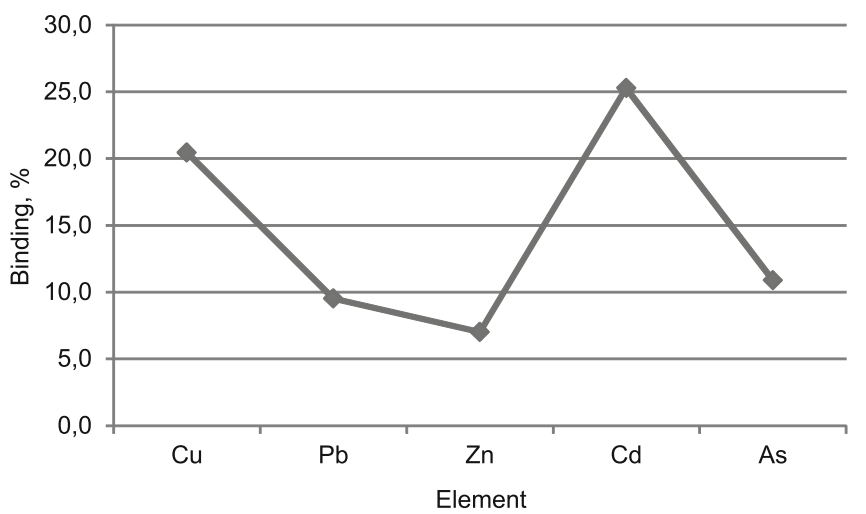

Figure 4. The total HM and As binding by the nano-agent in the soil
$\mathrm{HM}+\mathrm{As} / \mathrm{kg}$ (about $141.0 \mathrm{mg} \mathrm{Cu} / \mathrm{kg}, 64.8 \mathrm{mg} \mathrm{Pb} / \mathrm{kg}, 25.3$ $\mathrm{mg} \mathrm{Zn} / \mathrm{kg}, 0.9 \mathrm{mg} \mathrm{Cd} / \mathrm{kg}$ and $3.9 \mathrm{mg} \mathrm{As} / \mathrm{kg}$ ).

\section{CONCLUSIONS}

3-Aminopropyltrimethoxysilane nano-agent demonstrated a moderate effectiveness of binding of $\mathrm{Cu}, \mathrm{Pb}, \mathrm{Zn}$, $\mathrm{Cd}$ and As contained in the soil.

The examined product showed different binding efficiency of the individual elements depending on their form in the soil.

The highest percentage of binding by 3-Aminopropyltrimethoxysilane was observed for zinc and copper, and the lowest - for lead and arsenic.

No effect of the nano-agent concentration in the range of 0.1 and $0.5 \%$ on the efficiency of bindinig of heavy metals and arsenic was observed.

\section{LITERATURE CITED}

1. Rosada, J. The condition of an agricultural environment in Głogów Copper Smelter and Refinery impact area. RN IOR - PIB, (2008). [in Polish].

2. Kabata-Pendias, A. \& Pendias, H. (1993) Biogeochemistry of trace elements. PWN Warszawa. [in Polish].

3. Zimny, L. (2007). Definitions and division of farming systems, Acta Agrophys. 10(2), [in Polish].

4. Karczewska, A. (2002). Heavy metals in soils polluted by the emission from a copper smelter - forms and solubility Zesz. Nauk. AR in Wrocław pp. 159. ISSN 0867-7964 [in Polish].

5. Kabata-Pendias, A., Piotrowska, M. \& Witek, T. (1993). The evaluation of quality and capabilities of agricultural use of soils contaminated by heavy metals. In "The evaluation of soil and plants contamination by heavy metals and sulfur". Framework of guidance for agriculture. IUNG Puławy. [in Polish].

6. DIRECTIVE 2010/75/EU OF THE EUROPEAN PARLIAMENT AND OF THE COUNCIL of 24 November 2010 on industrial emissions (integrated pollution prevention and control).

7. Ghormade, V., Deshpande, M.V. \& Paknikar, K.M. (2011). Perspectives for nano-biotechnology enabled protection and nutrition of plants, Biotechnology Advances, 29, 792-803.

8. Grzesiak, P., Kurczewska, J. \& Schroeder, G. (2011). Nanotechnology for agriculture (15-34). In: Environment and industry. Volume 2. (Eds. G. Schroeder, P. Grzesiak), Cursiva Poznań, pp. 176, ISBN 978-83-62108-14-5. [in Polish].

9. Nanoscience and nanotechnologies, Condition and perspectives of development [in Polish]. Ed. A. Mazurkiewicz, Institute for Sustainable Technologies Publishing House - PIB, Radom, 2007.

10. European Nanotechnology Gateway, Nanotechnology in agriculture and food, nanoforum.org (May 2006).

11. Grzesiak, P., Łukaszyk, J., Grobela, M. \& Motała, R. The development of tendencies and possibilities of the application of nano-processes and photocatalysis in agriculture. The report IOR-PIB nr 213/2012. [in Polish].

12. Motała, R., Grzesiak, P., Grobela, M. \& Łukaszyk, J. (2011). The study of $\mathrm{SO}_{2}$ oxidation reaction rate at the catalyst based on recovered carrier from the spent vanadium masses (79-96). In Environment and industry. Volume 2. (Eds. G. Schroeder, P. Grzesiak), Cursiva Poznań, pp. 176 ISBN 97883-62108-14-5 [in Polish].

13. Tessier, A., Campbell, P.G. \& Bission, M. (1979). Sequential extraction procedure for the speciation of particulate trace metals. Anal. Chem. 51, 844-851. 